\title{
Analysis of Determining Factors of Teacher Performance in Integrated Social Science Learning in Tanah Datar Junior High School
}

\author{
Lia Pramita Indah Tiara ${ }^{1}$, Yulhendri ${ }^{2}$, Erni Masdupi ${ }^{3}$ \\ ${ }^{1}$ Universitas Negeri Padang, Padang, Indonesia, $\square$ Liapramitatiara388@gmail.com. \\ ${ }_{2}^{2}$ Universitas Negeri Padang, Padang, Indonesia, $\triangle$ yulhendrisutan@yahoo.co.id \\ ${ }^{3}$ Universitas Negeri Padang, Padang, Indonesia, $\square$ emasdupi@yahoo.com
}

\begin{abstract}
This study aims to reveal : 1) factors that influence the performance of teachers in integrated social science learning in Tanah Datar District 2) determine the determinants of the performance of Integrated Social Studies teachers in the Tanah Datar District Public Junior High School. This type of research is the 2nd Confirmatory Factor Analysis (CFA) study using the structural equation modeling (SEM) method. The population in this study were all Integrated Social Studies teachers in Tanah Datar District Public Junior High School as many as 138 people. The sample is determined based on the proportional random sampling method, as many as 103 people. Data collection by distributing questionnaires to teachers of Integrated Social Sciences subjects at the Tanah Datar District Junior High School. The data analysis technique used was factor analysis with the help of SmartPLS. Results of the study are: 1) Teachers ability, 2) achievement motivation 3) Facilities and infrastructure, 4) Work Motivation, 5) job satisfaction, 7) self-commitment, 7) work environment, 8) educational background.
\end{abstract}

Keywords: teacher performance

\section{Introduction}

The country of Indonesia is one of the countries that have a large population. The population faces many problems, especially education problems. The fundamental problem of education in Indonesia is that the level of education is relatively low, the dynamics of changes in population structure have not been fully accommodated in education development, education gap, good governance that has not run optimally, inadequate and equitable education service facilities, relatively low quality education able to meet the competencies of students, higher education still faces obstacles in developing and creating science and technology, education management has not run effectively and efficiently, the education development budget has not been adequately available (Irianto, 2013: 11). By improving this education problem, the Indonesian population should be formed into productive and creative human beings in order to create an advanced nation and country.

The problem with the quality of education is very closely related to education personnel consisting of teachers and lecturers and the prevailing education system. The government applies regulations to achieve educational goals while teachers directly educate, teach, guide, direct, train, assess, and evaluate students (Law Number 14 of 2014). One of the government's efforts to achieve the goal of education is to change the curriculum, such as in elementary schools (SD) and junior high schools (SMP), changing social studies into integrated social studies.

Sumantri (2001: 89) argues that social studies education is an educational program and not a separate sub-discipline, so it will not be put forward either in the philosophy of nomenclature of science, social sciences, and education. this means that integrated social studies are a unit of social science, such as economics, geography, history, sociology, anthropology, psychology and so on. It is hoped that social studies education given in schools can provide insight and knowledge about the basic concepts of social science with the aim of education so that students have sensitivity and awareness of social problems faced in their environment, and are able to find solutions or good solutions to the problems they face. , so that students who are built become responsible citizens. Thus Integrated Social Studies education is important to be applied to the social life of students. 
In the application of Integrated Social Studies the teacher experiences several difficulties such as the integrated Social Science curriculum itself does not yet describe an integrated unit, but is still separated between the fields of social sciences, the background of the teacher's ability to master the material outside the field, the teacher's workload to master materials outside of their fields, inadequate time, infrastructure and facilities that are less supportive (Ministry of National Education, 2007: 5). Problems with the background of the teacher who teaches Integrated Social Studies subjects are also found in Tanah Datar District, where teachers who teach Integrated Social Studies subjects come from several fields of study. Data on teacher education background in Tanah Datar Regency can be seen in Table 1.

Table 1 Background in the Field of Study of Integrated Social Studies Teachers at Tanah Datar Junior High School

\begin{tabular}{llll}
\hline Number & Educational Background & Amount & $\mathbf{\%}$ \\
\hline 1 & History & 13 & 25 \\
\hline 2 & Economy & 18 & 34.62 \\
\hline 3 & Geography & 14 & 26.92 \\
\hline 4 & Sociology & 1 & 1.92 \\
\hline 5 & $<$ S1 & 6 & 11.54 \\
\hline & Amount of & 52 & 100
\end{tabular}

Source: Head of the Tanah Datar District Junior High School 2017

Based on the above data, it can be seen that integrated social studies subject teachers in each Public Junior High School in Tanah Datar District generally have varied backgrounds in the field of study. Where the teachers only come from an educational background in one of the fields of study, so that in the learning process the teacher experiences difficulties. The difficulties faced by the teacher during the learning process will affect the teacher's performance.

Rachmawati (2013: 16) what is meant by teacher performance is the ability shown by the teacher in carrying out their duties and work, where performance is said to be good and satisfying if the results achieved are in accordance with established standards. The standard of teacher performance can be seen from the Uji Kompetensi Guru (UKG) value obtained. UKG is Teacher Competency Test, an examination activity to measure basic competencies about subject matter and teacher's pedagogical abilities. The greater the UKG value obtained, the higher the teacher's performance. The teacher's UKG value for group III must be greater than 75 while for group IV the UKG value is greater than 85 . The following are UKG values in several Tanah Datar Junior High Schools, which can be seen in Table 2.

Table 2 The Value of Integrated IPS UKG in Tanah Datar District Junior High School

\begin{tabular}{|c|c|c|c|c|c|c|c|}
\hline \multirow[t]{2}{*}{ Group } & \multicolumn{2}{|c|}{$\begin{array}{c}\text { Number of } \\
\text { Teachers }\end{array}$} & \multirow[t]{2}{*}{$\begin{array}{c}\text { Average } \\
\text { UKG Value }\end{array}$} & \multicolumn{2}{|c|}{$\begin{array}{c}\text { Number of } \\
\text { Teachers Above } \\
\text { UKG Value } \\
\end{array}$} & \multicolumn{2}{|c|}{$\begin{array}{l}\text { Number of Teachers } \\
\text { Below UKG Value }\end{array}$} \\
\hline & Teacher & $\%$ & & amount & $\%$ & Amount & $\%$ \\
\hline III & 21 & 70 & 78 & 12 & 57,1 & 9 & 100 \\
\hline \multirow[t]{2}{*}{ IV } & 9 & 30 & 89 & 9 & 42,9 & - & 0 \\
\hline & 30 & 100 & & 21 & 100 & 9 & 100 \\
\hline
\end{tabular}

Source: Teacher of Tanah Datar Junior High School

From the table above, it can be seen that the number of teachers in group three is more than the fourth class teacher. From the average UKG value, information was obtained that the fourth-grade UKG value was higher than the third group. In group four all teachers have UKG values above the average. However, in the third group, there are still many teachers who have below average UKG values and do not meet the UKG value standard, which is $57.14 \%$. This indicates that there are still 
many teachers in Tanah Datar Junior High School who do not meet the standards and must be improved to achieve better results.

The results of interviews conducted with teachers of Integrated Social Sciences subjects at Tanah Datar District Junior High School obtained information that the teacher had difficulties during the learning process. These difficulties can be influenced by several factors that lead to less effective learning of integrated social studies. Based on the survey results, these difficulties include the lack of the teacher's ability to master Integrated Social Sciences material because the teacher who teaches comes from one field of study, it is difficult to determine learning methods, educational background, facilities and infrastructure that do not support, do not master the material as a whole, difficulties in obtaining reading material, limited media, difficulty in determining learning methods, difficulties in using IT, limited time allocation, low student motivation, work motivation, preparation of learning plans seem complicated and difficulties in learning evaluation. Teachers who are able to overcome their difficulties during the teaching process will have good performance. From the problems identified above, it is known that teachers at Tanah Datar Junior High School have obstacles in improving their performance. In improving teacher performance, many factors influence it. The ability or competence of teachers to teach well will improve teacher performance. Kunandar (2008) means ability is something that is owned by someone to do the tasks and jobs that are charged to him. What is meant by the ability to teach is the ability of the teacher to carry out his duties in accordance with the competencies he has to carry out the learning process. To improve the ability or competence of teaching teachers, the teacher must have good pedagogical skills in carrying out the learning process. Setyono and Sudjadi (2011) reveal the importance of competencies possessed by teachers to improve teacher performance. This is reinforced by Kubrický and Cástková (2015) suggesting the competencies that teachers have are important in doing their jobs. Iskandar and Sumitra (2012) revealed that there was a pedagogic contribution to teacher performance.

Educational backgrounds that are appropriate to the subjects taught are needed for teacher understanding of the subjects taught. In Law No. 14 of 2005 explained that the academic qualification to be a teacher is the academic qualifications obtained by the teacher obtained through higher education undergraduate programs or four diplomas. Furthermore, teachers who have taken undergraduate education should have competence in their fields. Integrated social studies subjects can be taught by teachers with an integrated social studies background, economics, history, sociology, and geography. The importance of educational background to teacher performance is examined by Avalos (2011), who found that to form a good performance the level of teacher professionalism must be increased. The development of this teacher's professionalism is the impact of his title. Thus the background is important in improving performance. Furthermore, Nasution and Elytasari, et al. (2015) revealed that educational background influences teacher performance.

To support the learning process that runs well, adequate facilities and infrastructure are needed. Sanjaya (2009) explains that facilities are all things that are directly related to students which include learning media, learning tools, school supplies, etc. while infrastructure everything that is not directly related to students, but can support the smooth learning process of students which includes roads to school, school lighting, restrooms, and so on. A teacher is required to be able to use and use infrastructure to support students during the learning process

To prove the influence of facilities and infrastructure on teacher performance, Djatmiko (2006) conducted research at Semarang City Public Junior High School. The results of the study show that facilities and infrastructure significantly influence teacher performance. Suwarno, et al (2013) conducted a study to find out the relationship between facilities and infrastructure to teacher performance. The results of the study indicate that there is a positive relationship between facilities and infrastructure and teacher performance. This means that the availability of adequate facilities and infrastructure will increase teacher performance. While Kirimi, et al (2013) recommend providing appropriate learning facilities in schools for more effective teaching.

In carrying out work, someone needs the motivation to do something. To do the work, the teacher needs a strong motivation to carry out the teaching and learning process. Danim (2004) argues that 
work motivation is any power that emerges from within an individual to achieve certain goals or advantages in the work environment or in the yard of life in general. The importance of motivation on teacher performance has been proven by previous research. Pujianti and Isroah (2014) found that there was an influence of work motivation on teacher performance. This means that one of the factors that influence teacher performance positively and significantly is work motivation. Haruthaithanasan (2018) revealed the importance of conducting school reforms to obtain better performance, where school reform requires teacher motivation to obtain better performance. So the teacher's work motivation is needed to achieve better performance.

In addition to work motivation, teacher motivation for achievement will also affect teacher performance. Achmadi (2012) found that there was a positive and significant relationship between achievement motivation and teacher performance. Thus achievement motivation is important to improve teacher performance. MacFarlane (2013) revealed that teacher achievement motivation is very important, therefore school principals should be able to improve teacher performance, through improving teacher attitudes and teacher participation in seminars.

Furthermore, which supports good performance is a work environment factor. Basuki and Susilowati (2005) explain that the work environment is anything that is in the environment that can affect both, directly and indirectly, someone or a group of people in carrying out their activities. The more harmonious the interwoven work environment will help the teacher in improving his performance. This has been proven by previous research, Setyono and Sudjadi (2010) and Ruscahyono (2014) found that there was a positive and significant influence on the work environment towards teacher performance. Hidayah and Sugiarto (2015) explain that one of the factors that influence teacher performance is the work environment. With a good work environment will improve the ability of teachers and will have an impact on teacher performance.

Teachers who already have good motivation should be able to maintain a commitment to become a teacher who has good performance. Hasibuan (2005) explains that someone's commitment to work is the ability of an employee or member of the organization to maintain value in an effort to achieve organizational goals in general. Inayatullah (2012) found that the contribution of self-commitment to teacher performance was $15.44 \%$. While Nurhayati (2011) found that one of the factors that significantly builds teacher performance is work commitment. Mrgrioiu (2015) argues that the commitment of teachers is able to overcome teacher difficulties.

Job satisfaction is needed by the teacher to assess how successful the teacher is in carrying out his work. Robbins \& Judge (2011) defines job satisfaction as a positive feeling in a job, which is an impact or an evaluation of various aspects of the job. Job satisfaction can improve teacher performance by assessing how much the teacher feels satisfied with his job, the greater the teacher's satisfaction in doing his work, the higher the teacher's performance. Demirta (2010) says that the very high level of teacher job satisfaction affects positively to achieve educational goals. If the educational goals are achieved, the teacher has a good performance. Nurhayati (2011) found that one factor that significantly builds teacher performance is job satisfaction. Furthermore, Inayatullah (2012) found that the contribution of self-commitment to teacher job satisfaction was $15.27 \%$. Corina (2012) explains that the importance of teacher satisfaction to improve teacher performance. Different results were found by Ruscahyono (2014) who stated that there was no influence between job satisfaction on teacher performance.

\section{Methods}

This type of research is classified as descriptive comparative. This type of research is comparative by using the method of applying the 2nd Confirmatory Factor Analysis (CFA), which is a study that aims to confirm the relationships contained in a problem. The population in this study were all-state junior high school teachers who taught Integrated Social Studies in Tanah Datar District. The number of teachers in Tanah Datar District Public Junior High School is 138 people with a sample of 103 people. Proportional Random Sampling sampling technique by lottery.Data collection tool in the form of a questionnaire to obtain primary data. 
Before the questionnaire was distributed, the questionnaire was arranged in advance based on variable indicators. The indicator is used as a starting point for compiling instrument items in the form of statements. Each answer given by the respondent is given the value of supporting or rejecting the statement. Value statements based on a Likert scale that support positive and negative statements. For positive statements, the order of values is strongly agreed (5), agree (4), doubtful (3), disagree (2), and strongly disagree (1). After the statement is made, the statement is first tested on 30 respondents outside the population to test the validity and reliability of the questionnaire. The data obtained were processed by descriptive analysis techniques and Structural Equation Modeling (SEM) analysis.

\section{Results and Discussion}

\section{Results}

Based on the results of the study by distributing questionnaires to 103 Integrated Social Studies teachers at Tanah Datar Junior High School, data were obtained which were then tabulated and processed. Based on the processed data obtained distribution, frequency, and percentage of data. In the variable description, the conclusion is the withdrawal of the conclusion based on the Respondent's Achievement Rate (TCR). To be clearer about TCR, see Table 3.

Based on the results of the descriptive analysis in Table 3, it can be seen that the TCR variable teaching ability, educational background, facilities and infrastructure, work motivation, achievement motivation, work environment, self-commitment, and job satisfaction are in a good category. This shows that the respondent's answers are able to describe each variable well.

Table 3 Distribution of Frequency of Respondents' Answers

\begin{tabular}{lllll}
\hline Number & Variable & Average & TCR & Category \\
\hline 1 & Teaching Ability & 4.36 & 87.1 & Good \\
\hline 2 & Educational Background & 4.37 & 87.36 & Good \\
\hline 3 & facilities and infrastructure & 4.35 & 87.02 & Good \\
\hline 4 & Work Motivation & 4.40 & 87.96 & Good \\
\hline 5 & Achievement Motivation & 4.33 & 86.55 & Good \\
\hline 7 & Working Environment & 4.33 & 86.60 & Good \\
\hline 8 & Self Commitment & 4.34 & 86.89 & Good \\
\hline
\end{tabular}

Source: 2018 Primary Processed Data

Based on the results of the descriptive analysis, it can be seen that the TCR variable teaching ability, educational background, facilities and infrastructure, work motivation, achievement motivation, work environment, self-commitment, and job satisfaction are in a good category. This shows that the respondent's answers are able to describe each variable well.

Research 2nd Confirmatory Factor Analysis (CFA) is a study that aims to confirm the relationships contained in a problem. To find out the forming factors of teacher's performance in Integrated Social Studies learning at Tanah Datar District Junior High School carried out by SEM analysis techniques. SEM analysis can be seen through the test of the outer model (Measurement Model). Test the outer model (Measurement Model) is carried out to test the contract validity and instrument reliability. The outer model test results are obtained by looking at the convergent Validity test and reliability test.

Convergent validity test is used to describe the correlation between contract and manifest variables. The greater the correlation value the better the relationship between the manifest variable. Correlation is declared valid with a loading factor value of $\geq 0.5$. Convergent validity test latent constructs of teaching ability can be seen in Table 4 . 
Table 4 Convergent Validity Test Results Teaching Ability

\begin{tabular}{llll}
\hline \multicolumn{2}{c}{ Manifest Variable } & & $\begin{array}{c}\text { Loading } \\
\text { Factor }\end{array}$ \\
\hline \multirow{2}{*}{1} & \multirow{2}{*}{ Ability to develop learning plans } & KM 1 & 0.622 \\
\cline { 3 - 4 } 2 & Ability to carry out learning & KM 2 & 0,723 \\
\cline { 3 - 4 } 3 & The ability to carry out interpersonal relationships & KM 4 & 0.713 \\
\cline { 3 - 4 } & KM 5 & 0,719 \\
\hline \multirow{2}{*}{4} & $\begin{array}{l}\text { Ability to carry } \\
\text { assessment }\end{array}$ & KM 6 & 0,534 \\
\hline
\end{tabular}

Source: Primary Data Processed Results, 2018

Convergent test results validity of teaching ability in the table above is declared valid. This is caused by the value of loading factor $\geq 0.5$. This means that all manifest variables of teaching ability can be included in further testing. The value of loading the highest teaching ability factor is the ability of the teacher to compile a learning scenario. This indicates that in improving the ability of teachers of Integrated Social Sciences subjects at Tanah Datar Public Junior High School requires preparation to carry out the learning process.

Convergent validity test latent construct of educational background can be seen in Table 5 .

Table 5 Convergent Validity Test Results Background of Education

\begin{tabular}{llll}
\hline ManifestVariable & & Loading Factor \\
\hline 1 & $\begin{array}{l}\text { Education is in accordance with the subjects } \\
\text { taught }\end{array}$ & LBP1 & 0.786 \\
\hline 2 & Competent in teaching social studies subjects & LBP2 & 0.882
\end{tabular}

Source: Primary Data Processed Results, 2018

The convergent test results of the validity of the educational background in the table above are declared valid. This is caused by the value of loading factor $\geq 0.5$. This means that all manifest variables of teaching ability can be included in further testing. The manifest variable of educational background that has the highest value of the loading factor is competent in teaching social studies subjects. This indicates that the background in accordance with the subjects possessed has a role in improving teacher performance.

Convergent test validity construct latent facilities and infrastructure can be seen in Table 6 .

Table 6 Convergent Validity Test Results for Facilities and Infrastructure

\begin{tabular}{lllll}
\hline \multicolumn{2}{l}{ ManifestVariable } & & & Loading Factor \\
\hline 1 & Utilizing facilities & and & SP 1 & 0.734 \\
& infrastructure & & SP 2 & 0.687 \\
\hline 2 & Using facilities & and & SP 3 & 0.627 \\
& infrastructure & & SP 4 & 0.713 \\
\hline
\end{tabular}

Source: Primary Data Processed Results, 2018

The convergent test results for the validity of the facilities and infrastructure in the table above are declared valid. This is caused by the value of loading factor $\geq 0.5$. This means that all manifest variables of facilities and infrastructure can be included in further testing. The highest value of loading factor for facilities and infrastructure is utilizing facilities and infrastructure in the form of utilizing the environment and facilities provided by the school. This means that Integrated Social Studies teachers in Tanah Datar District have been able to utilize existing media lessons.

Convergent validity test latent construct Work motivation can be seen in Table 7 . 
Table 7 Convergent Validity Test Results for Work Motivation

\begin{tabular}{|c|c|c|c|}
\hline \multicolumn{3}{|c|}{ ManifestVariable } & \multirow{2}{*}{$\begin{array}{c}\text { Loading Factor } \\
0.705\end{array}$} \\
\hline 1 & Perseverance & MK1 & \\
\hline & & MK2 & 0.860 \\
\hline 2 & Happy feeling & MK3 & 0.675 \\
\hline
\end{tabular}

Source: Primary Data Processed Results, 2018

Convergent test results validity of work motivation in the table above is declared valid. This is caused by the value of loading factor $\geq 0.5$. This means that all manifestations of work motivation variables can be included in further testing. The manifest variable of work motivation which has the highest value of loading factor is the perseverance of teachers in work which can be seen from the participation of teachers in participating in the Integrated IPS MGMP.

Convergent validity test latent constructs of achievement motivation can be seen in Table 8 .

Table 8 Convergent Validity Test Results Motivation for Achievement

\begin{tabular}{|c|c|c|c|}
\hline & Manifest Variable & & Loading Factor \\
\hline 1 & $\begin{array}{l}\text { Trying to do something with new and } \\
\text { creative ways }\end{array}$ & MB1 & 0.784 \\
\hline 2 & Looking for feedback about his actions & $\begin{array}{l}\text { MB2 } \\
\text { MB3 }\end{array}$ & $\begin{array}{l}0.868 \\
0.837\end{array}$ \\
\hline
\end{tabular}

Source: Primary Data Processed Results, 2018

The convergent validity test results of achievement motivation in the table above are declared valid. This is caused by the value of loading factor $\geq 0.5$. This means that all manifest variables of achievement needs can be included in further testing. The manifest achievement motivation variable that has the highest loading factor value is looking for feedback about its actions in the form of getting an award or high value.

Convergent validity test latent construct work environment can be seen in Table 9 .

Table 9 Results of the Convergent Validity Test of the Work Environment

\begin{tabular}{|c|c|c|c|}
\hline & Manifest Variable & & Loading Factor \\
\hline 1 & Work atmosphere & LK1 & 0.774 \\
\hline 2 & $\begin{array}{l}\text { Relationship with co- } \\
\text { workers }\end{array}$ & $\begin{array}{l}\text { LK2 } \\
\text { LK3 }\end{array}$ & $\begin{array}{l}0.845 \\
0.759\end{array}$ \\
\hline
\end{tabular}

Source: Primary Data Processed Results, 2018

The results of the convergent validity teaching ability in the table above can be included in further testing. This is caused by the value of loading factor $\geq 0.5$. This means that all work environment manifest variables are declared valid. The manifest variable of the work environment that has the highest value of loading factor is the relationship with colleagues in the form of a harmonious relationship, both with colleagues and with students.

Convergent validity test for latent commitment can be seen in Table 10.

Table 10 Convergent Validity Test Results of Self Commitment

\begin{tabular}{llll}
\hline & Manifest Variable & & Loading Factor \\
\hline 1 & Teacher's willingness & KD1 & 0.768 \\
& & KD2 & 0.754 \\
\hline 2 & Pride of the Teacher & KD3 & 0.687 \\
\hline 3 & The loyalty of Teacher & KD4 & 0.533 \\
\hline \multicolumn{5}{l}{ Source: Primary Data Processed Results, 2018 }
\end{tabular}


Convergent test results validity of self-commitment in the table above is declared valid. This is caused by the value of loading factor $\geq 0.5$. This means that all self-commitment manifest variables can be included in further testing. The manifest commitment of self variable which has the highest loading factor is the willingness of the teacher in the form of the teacher's willingness to complete the task according to the standard set and on time.

Convergent validity test latent constructs of job satisfaction can be seen in Table 11

Table 11 Convergent Validity Test Results for Job Satisfaction

\begin{tabular}{llll}
\hline \multicolumn{2}{l}{ ManifestVariable } & & Loading Factor \\
\hline 1 & Work-related matters & KM1 & 0.680 \\
& & KM2 & 0.864 \\
\hline \multirow{2}{*}{3} & Matters relating to superiors & KM4 & 0.621 \\
\hline Matters relating to facilities & KM3 & 0.777 \\
& in the work environment & & \\
\hline
\end{tabular}

Source: Primary Data Processed Results, 2018

Convergent test results validity of teaching ability in the table above is declared valid. This is caused by the value of loading factor $\geq 0.5$. This means that all manifest job satisfaction variables can be included in further testing. The manifest variable of job satisfaction that has the highest value of loading factor is things related to work in the form of teacher satisfaction in teaching in accordance with the field of science and skills.

The next Outer model test is reliability testing. Reliability test aims to describe the consistency and stability of measuring instruments or research instruments in measuring a concept or construct. Instruments are said to be reliable if the answers to statements are consistent or stable over time. Test the reliability of latent constructs using the value of Composite Reliability and Cronbach's Alpha. The instrument was declared reliable if the value of loading latent constructs was $>0.7$. But for research on the development of the scale of loading values, the latent constructs of 0.50 to 0.60 can still be accepted. The results of the reliability test of each latent construct can be seen in Table 12 .

Table 12 Reliability Test Results

\begin{tabular}{lcc}
\hline Latent Composite & Composite Reliability & Cronbach's Alpha \\
\hline Teaching Ability & 0.832 & 0.765 \\
\hline Educational Background & 0.821 & 0.573 \\
\hline Facilities and Infrastructure & 0.785 & 0.640 \\
\hline Work Motivation & 0.793 & 0.606 \\
\hline Achievement Needs & 0.869 & 0.775 \\
\hline Work Environment & 0.836 & 0.704 \\
\hline Self Commitment & 0.783 & 0.631 \\
\hline Job Satisfaction & 0.820 & 0.720 \\
\hline
\end{tabular}

Source: Primary Data Processed Results, 2018

From the table above it can be seen that the reliability composite value and Cronbach's alpha all latent constructs are above 0.5 . Which means that all latent constructs in this study can be continued for further testing. After evaluating the outer model and testing its reliability, the final model image of the research that will be included in the testing of the inner model can be seen in the following figure: 


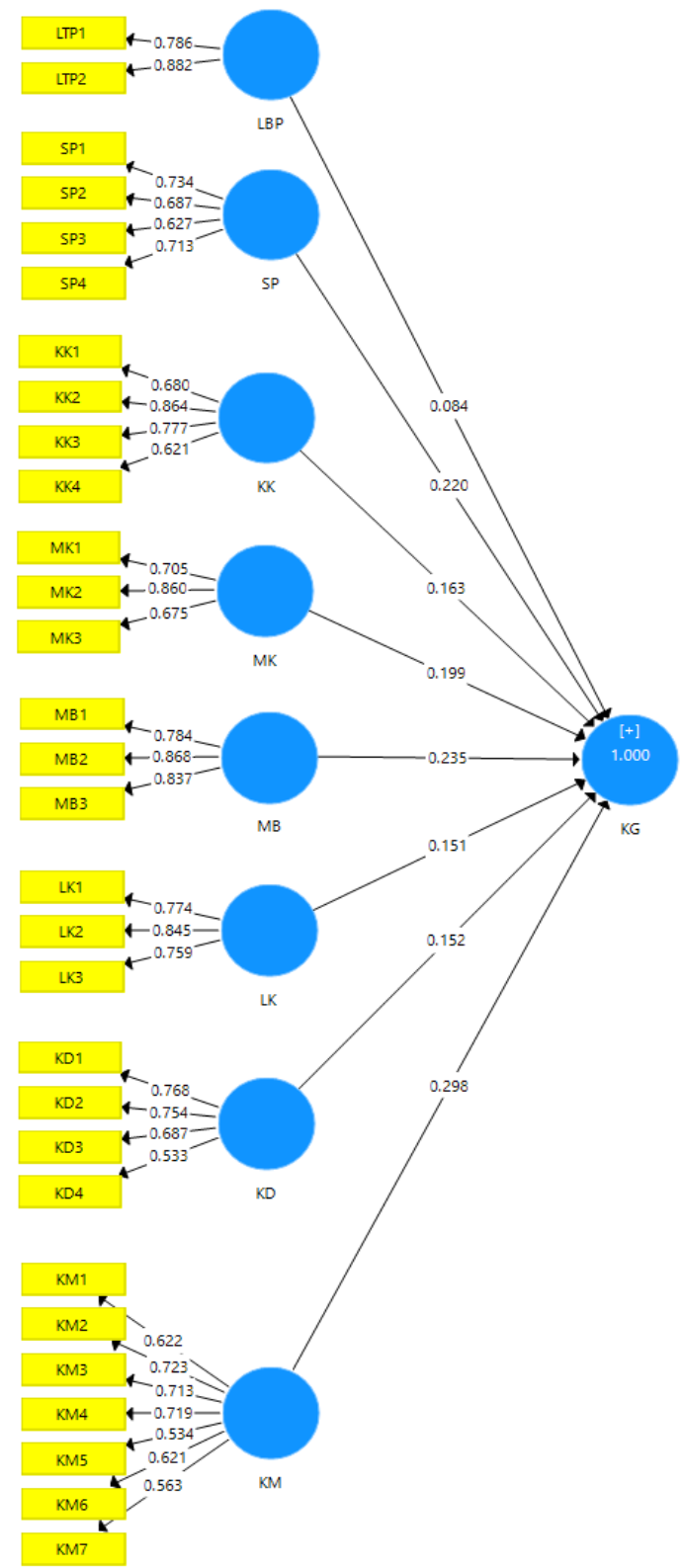

Figure 1. 2nd CFA Final Model

\section{Discussion}

The discussion of the results of this study was based on the results of both descriptive and analysis of the 2nd CFA. Based on the analysis carried out teaching ability is the main form of teacher performance. This can be seen from the teaching ability coefficient of 0.271 . Thus the cause of the high performance of Integrated Social Studies teachers is a factor in his teaching ability. Therefore to form better teacher performance, the ability to teach teachers is very necessary. this is in line with the statement of Dale (2000: 70) which states that the one that affects teacher performance is internal factors, including the ability. The better a person's teaching ability will have an impact on the high performance produced by a teacher.

The coefficient value of latent constructs for the needs of achievement based on the results of the model analysis test is 0.240 . This figure is the second largest number that causes the performance of Integrated Social Studies teachers to be high. McClelland (1987) the importance of the need for achievement in improving performance, he explained that someone who has a strong drive to succeed in pursuing personal achievement is more than a reward for success. However, to improve 
performance better the teacher should increase the motivation for achievement by means of the teacher doing the learning process in new and creative ways.

The value of the latent construct coefficient of facilities and infrastructure based on the results of the model analysis test is 0.221 . This figure is the third largest number that causes the performance of Integrated Social Studies teachers to be high or low. Facilities and infrastructure play a role to help students and teachers in the learning process. The more adequate facilities and infrastructure exist, the better the learning process will be and the learning objectives will be achieved. Arikunto (2004: 41) says one of the factors that influence teachers in working with facilities and infrastructure. However, to improve performance better, teachers should be better able to use available facilities and infrastructure.

The coefficient value of the work motivation latent construct based on the results of the model analysis test is 0.204 . This figure is the fourth that causes the performance of Integrated Social Studies teachers to be high in Tanah Datar District. Work motivation plays a role in encouraging someone to do something. With high work, motivation will have an impact on increasing one's performance. Mangkunegara (2001: 45) and Yamin (2010: 129) both identify that one of the factors that influence a person's performance is work motivation. To increase the motivation of the teacher's work, the teacher should improve his feelings of pleasure in teaching. This can be done by loving the work given.

The coefficient value of latent construct of job satisfaction based on the results of the model analysis test conducted is equal to 0.161 , this number is the fifth which causes the performance of the Integrated Social Studies teacher to be high in Tanah Datar District. A person will feel satisfied with his job if he has a good evaluation of his work. The high evaluation will describe the teacher's high performance. Therefore, the more satisfied the teacher of his work will be illustrated through the evaluation of his work and will have an impact on his performance. Demirta (2010) says that the very high level of teacher job satisfaction affects positively to achieve educational goals. If the educational goals are achieved, the teacher has a good performance. However, to create better job satisfaction teachers should increase satisfaction with their work environment. One effort to increase teacher satisfaction in the work environment is by maintaining harmony in the work environment.

The coefficient value of the latent self-commitment construct based on the results of the model analysis test is 0.160 . This figure is the sixth which causes the performance of the Integrated Social Studies teacher to be high in Tanah Datar District. A person's commitment is needed in carrying out his work because, with a high work commitment, the person will be active, serious, responsible and have good loyalty to the work, leadership, and organization where he works. With the existence of a good self, the commitment will help teachers to achieve their goals. The teacher's goals achieved will affect the teacher's performance. Thus commitment affects teacher performance.

Majid (2005: 45) and Yamin (2010: 129) both identify that one of the factors that influence teacher performance is the teacher's commitment to work. To improve self-commitment better the teacher should be more willing to do all the tasks and responsibilities given. One effort to increase the willingness of teachers to do the tasks and responsibilities given is by utilizing the more free time to complete work, both administrative work, and non-administrative work.

The coefficient value of the latent construct of the work environment based on the results of the model analysis test is equal to 0.156 . This number is the seventh which causes the performance of Integrated Social Studies teachers to be high in Tanah Datar District. A good work environment is needed to improve teacher performance. A good work environment will be realized if the creation of an activity that is optimal, safe, and comfortable. Dale (2000: 70) and Arikunto (2004: 41) both identify that one of the factors that influence teacher performance is the work environment. To create a better work environment teachers should be better able to create a better working atmosphere. One effort to improve a good working atmosphere is to create a more harmonious working atmosphere.

The coefficient value of the latent construct of educational background based on the results of the model analysis test is 0.091 . This figure is the last which causes the performance of Integrated Social Studies teachers to be high in Tanah Datar District. In social studies learning Integrated teachers come 
from different education such as economics, history, and geography. Of course in Social Studies learning Integrated teachers must be able to teach economics, history, and geography even though they come from different backgrounds. Once examined, the results of the study show that the educational background has the least influence compared to other latent constructs. In other words, the teacher's ability to teach is more important to achieve the goal than to see his educational background.

Conclusion

Based on the results of data processing and discussion of the results of research conducted with the 2nd Confirmatory factor analysis (CFA) analysis, to test the determinants of the performance of Integrated Social Studies teachers in Tanah Datar District Junior High School, conclusions can be drawn from eight factors analyzed, performance determinants the teacher is the teacher's ability to teach. The manifest variable which has the greatest correlation is the teacher's ability to build interpersonal relationships. This means that the teacher's ability to build interpersonal relationships is the most powerful foundation in determining the performance of Integrated Social Studies teachers in Tanah Datar. While the least factor in determining teacher performance is educational background. This is due to the low correlation value of the manifest variable of teacher education in accordance with the subjects taught.

Suggestion

Based on the results of the study the authors recommend that Integrated Social Studies teachers improve and maintain teacher performance by improving teacher teaching skills by improving science and technology mastery so as to create more meaningful learning, Increase teacher achievement motivation by conducting learning processes in new and creative ways, improving abilities teachers to use learning media well during the learning process such as using more varied learning media, increasing teacher work motivation by loving their work, increasing job satisfaction by increasing harmony in their work environment, and increasing the willingness of teachers to do the tasks and responsibilities that given by using more free time to complete work, both administrative work and non-administrative work. For principals the authors suggest improving teacher performance by providing adequate facilities and infrastructure, monitoring and rewriting teachers who have good performance, in conducting Integrated Social Studies learning, they should be more focused on the ability of teachers to teach compared to their educational background, and able to create a safe, comfortable and harmonious working atmosphere.

\section{References}

Achmadi. Relationship between Principal Leadership, Achievement Motivation, and Compensation with Primary School Teacher Performance. Journal of Educational Management (Vol. 1 No. 3)

Arikunto, Suharsimi. 2004. Basics of Educational Evaluation. Jakarta: Bumi Aksara.

Avalos, Beatrice. 2011. Teacher Professional Development in Teaching and Teacher Education Over Ten Years. Procedia - Social and Behavioral Sciences 27, Pages 10-20.

Basuki and Indah Susilowati. 2005. Impact of Leadership and Work Environment on Work Spirit. Indonesian Research Journal (Vol. 1, No. 1).

Corina, Bentea Cristina. 2012. Some Determinative Factors Job Motivation. Procedia - Social and Behavioral Sciences 47, Pages 1638 - 1642.

Dale, Timpe A. 2000. Series of Human Resource Management, Leadership. Jakarta: Gramedia.

Department of National Education 2007. Regulation of the Minister of National Education of the Republic of Indonesia, Number 16 of 2007, Regarding Academic Qualification Standards and Teacher Competencies. Jakarta: Ministry of National Education.

Danim, Sudarwan. 2004. Motivation for Leadership and Group Effectiveness. Jakarta: Rineka Cipta.

Demirta, Zülfü. 2010. Teachers' Job Satisfaction Levels. Procedia Social and Behavioral Sciences 9, Pages 1069-1073. 
Djatmiko, Eko. 2006. Effect of Principal Leadership and Infrastructure on Teacher's Performance in Semarang City Junior High School. Economic Focus (Vol. 1, No. 2, December) Pages 19-30, ISSN: 1907-6304.

Elytasari, Novi, Wilson, and Nurlita. 2015. Effects of Background on PAUD Teacher Education on Teacher Performance in Ujung Batu District, Rokan Hulu Regency. Online Journal of Teacher Training and Education (Vol. 2, No.1).

Hasibuan, Malayu S.P. 2005. Human Resource Management. Jakarta: Bumi Aksara.

Irianto, Agus. 2013. Education as an Investment in the Development of a Nation. Kencana: Jakarta.

Haruthaithanasan, Theera. 2018. Effects of Educational Reforms in the 2nd Decade (2009-2018) on Teacher Motivation and Student Achievement Among Schools in Southern Thailand. Kasetsart Journal of Social Sciences 39, Pages 22 -229.

Hidayah, Isti and Sugiarto. 2015. Model of Independent Working Group of Teachers and Its Effectiveness towards Elementary School Teacher Ability in Conducting Mathematics Learning. Procedia - Social and Behavioral Sciences 214, Pages 43 - 50.

Inayatullah. 2012. Contributions of Internal and External Factors to Teacher Professional Performance Improvement. Region (Vol. 3, No. 1).

Iskandar, Sentot and Itot Tito Sumitra. 2012. Effect of Teacher Potential and Infrastructure on Teacher Performance and Its Implications on Service Quality in SMP Negeri 7 Bandung. Journal of Economics, Business \& Entrepreneurship (Vol. 6, No. 2), Pages 77-84, ISSN 243-0633.

Kirimi, Florence Kaumi, et al. 2013. Influence of Selected Motivational Factors on the Performance of Secondary School of Agriculture Teachers in Imenti South District, Kenya. International Journal of Education and Research (Vol.1, No. 6)

Kubrický, Jay and Pavlína Cástková. 2015. Teacher's Competence For The Use Of Web Pages In Teaching As A Part Of ICT Education Technical Teacher's Competences. Procedia - Social and Behavioral Sciences 17, Pages 3236-3242.

Kunandar. 2008. Easy Steps to Follow Classroom Research as. Teacher Professional Development. Jakarta: PT. Raja Grafindo Persada.

Maftukhah, Lina, Harnanik, and St. Sunarto. 2012. Factors Affecting Class VII Integrated Social Studies Learning Difficulties at State Junior High School 1 in Kendal District. Economic Education Analysis Journal (Vol. 1, No. 1), ISSN 2252-6544.

Majid. Abdul. 2005. Learning Planning Developing Standards. Teacher Competence. Bandung: PT Remaja Rosdakarya.

Mangkunegara, Anwar Prabu. 2001. Human Resource Management. Bandung: Teenager Rosdakarya.

MacFarlane, Kate, Lisa Marks Woolfson. 2013. Teacher Attitudes and Behavior Towards the Inclusion of Children with Social, Emotional and Behavioral Difficulties in Mainstream Schools: An Application of the Theory of Planned Behavior. Teaching and Teacher Education 29, Pages 4652.

McClelland, D.C. 1987. Human Motivation. New York: Cambridge University Press.

Mrgrioiu, Alina. 2015. Teachers' Commitment from Special Needs Schools - a Predictor of their Humanity and Loyalty. Procedia - Social and Behavioral Sciences 203, Pages 322 - 326.

Nurhayati. 2011. Building Performance Through Developing Teacher's Commitments in Semarang City. Economics and Business Magazine (Vol. 8, No. 1).

Pujiyanti and Isroah. 2014. Effects of Work Motivation and Work Discipline on Teacher Performance at Ciami 1 High School. Accounting Education Study, p. 184-207.

Rachmawati, Tutik and Daryanto. 2013. Assessment of Teacher's Professional Performance and Credit Score. Yogyakarta: Gava Media.

Robbins, Stephen P and Timotgy A. Judge. Organizational Behavior, Edition 16. Jakarta: Salema Empat.

Ruscahyono, Hesthi. 2014. Effect of Locus of Control and Work Environment on Teacher Performance of SMK 4 Klaten with Job Satisfaction as Intervening. Actual February Edition (Vol. 1, No. 2).

Sanjaya, Vienna. 2009. Educational Process-Oriented Learning Strategies. Jakarta: Kencana. 
Setyono, Hendro and Achmad Sudjadi. 2011. Effect of Teacher Competence, Incentives and Physical Work Environment on Teacher Performance at SMA 1 Patimun, Cilacap Regency. SAINTEKS (Vol. 7, No. 202).

Suwarno, Budi Koestoro, and Herpratiwi. 2013. Knowledge Relationship About Education, Work Motivation, And Infrastructure With Teacher Performance In Learning In Public Madrasah Tsanawiyah in South Lampung Regency. Journal of Educational Education Information Technology (Vol. 1, No. 5).

Yamin, M. 2010. Teacher Standards and Performance Assessment. Jakarta: Gaung Persada. 